\title{
Lecturer's beliefs and practice in integrating digital literacy into lesson
}

\author{
Yulmiati', Syahrul Ramadhan ${ }^{2}$, Mukhaiyar $^{3}$, Yendra $^{4}$, Belinda Analido $^{5}$ \\ \{yulmiati@stkip-pgri-sumbar.ic.id ${ }^{1}$ \} \\ ${ }^{1,4,5}$ STKIP PGRI Sumatera Barat, Indonesia \\ ${ }^{2,3}$ Universitas Negeri Padang, Indonesia
}

\begin{abstract}
This is case study at University level, Padang Indonesia, aimed to examining lecturer's beliefs and practice in integrating digital literacy into lesson. The data taken base on lecturers' interviewed following observations in class to explore lecturer's practice in using digital literacy. The participants of this study were four lecturers who teach English reading and writing. The data were analyzed qualitatively by explaining lecturers' beliefs of integrating digital literacy and their practice. As the result, the lecturers who teach writing and reading at university have a strong belief that integrating digital literacy into the lesson is essencial to do. Unfortunately, in practices, the lecturers use digital literacy limitedly on e-learning that must be used in the university as the requirement. It suggested that the lecturers should balance the reflection of their beliefs and practice in integrating digital literacy into lesson.
\end{abstract}

Keywords: beliefs, practice, and digital literacy

\section{Introduction}

In digital era, involving in educational world, digital literacy is an important issue to support development of teaching and learning process. Digital literacies are commonly understood as the various skills that can be learned to use information from technology. This become the demand of 21 century skills concerning to teachers' creativity in classroom practice. The skills and abilities of 21 st Century need to teach such skills that taxonomies, theorists, and researchers have emphasized the need for critical reading, synthesis of sources, and collaborative work [1].

Many perspectives offer recommendation on digital literacies to be practiced in the classroom [2]. In some ways, technology should be balanced in education that the skills students need for the future work is an issue that should be related to the college curriculum development. It means that individuals need to be mastered both technology and information literacy. This challenge should be considered by teachers related to the use of digital literacy in improving their teaching. So, it is suggested that in particular, information and communication technology skills should also be involved in teaching programs [3]. 
But, digital practices and information and communication technology skills becomes the problem related to digital literacy since the use of incomplete open resources, [4] and few teachers realized it in school contexts. So that, digital literacy is not easy to be implemented in classroom practice, the teachers need to integrate and develop digital literacies into lessons, curricula, and programs [5]. In this case, teachers' beliefs about digital literacy can guide the teachers to make it into practice in teaching learning process because beliefs is important for teacher to enrich their skill to evolve knowledge related to better understanding of using digital literacy in classroom.

Teachers' beliefs are assumed regarding to educational issues as the filter for instructional and curricular decision and actions [6]. Beliefs appear from the perspectives that what teachers feel to be success on making plan for classroom activities [7]. Beliefs also come from the past experience in teaching that give benefit for the teachers to make decisions for future teaching practice. Beliefs are also useful to guide teachers in preparing their teaching strategies that influence teacher's well-being, in creating language learners' learning environment, motivation, language achievement and ability [8]. In short, teachers' beliefs are important to improve educational process.

Concerning teaching practices, teachers acts are based on their beliefs [9]; thus in teaching learning process, the teachers need to be aware of their beliefs that related to their view of language, the social context of language, learning and learners, and also teaching situation. All these issues are related to globalization and digitalization that have been reshaped the communication that affect how and with whom to communicate [10].

Although beliefs are important to be considered in classroom practice, it is also possible for teachers to change their beliefs. In technology based classroom, teacher's educational beliefs can change substantively, demonstrating various views which shows that it is easier to change classroom practices rather than educational beliefs [6]. This condition is possible happened in other classrooms to be research. To be related with that, it was found that there were gaps between teacher's beliefs about teaching and the practices in the classroom [11]. It is commonly faced by the teachers that what they believed and their practices are different, because beliefs are considered as an ideal while practices are the realities.

This article is aimed to evaluate teachers' beliefs and practice in integrating digital literacy into the lesson, as case study in Padang Indonesian context, specifically in teaching English reading and writing at university level. It examines the relationship between the beliefs and classroom practice of the lecturers who teach English as a Foreign Language (EFL) in university level, because it is assumed that beliefs and practice are interrelated [6]. The analysis and discussion of the data were carried out under the research questions identified as how is lecturers' beliefs about the importance of using digital literacy in English Reading and Writing classes? How does the development interpersonal and social process happen in digital literacy utilization? How lecturers' practice of using digital literacy in teaching and assessment?

\section{Review of Related Literature}

\subsection{Digital Literacy}

Although the term of digital literacy has been used in 1980, nowadays it still becomes the popular issue cause of the development of technologies affect humans' life more and more. It is defined as the ability to communicate with information of hypertexts by using computer 
[12]. Then, the concept of digital literacy is viewed wider as the ability to understand and use information from various digital resources. In other words, digital literacy needs the ability to read and write by using information technology with the current era. Gilster (2007) claimed that digital literacy is about how to master ideas where the technical skills-based are emphasized on how digital literacy is promoted and taught.

Digital literacy refers to the practices of communicating, relating, thinking and being associated with digital media and how these media affects the kinds of literacy practices [13]. In short, the practices of reading and writing can be determined by the available of digital tools. In line with this view, digital literacies involve the use of digital technologies for encoding and accessing texts in communication which shows attitude and ability of individuals to use digital tools in term of to identify, access, manage, integrate, evaluate, analyze and synthesize digital resources, construct new knowledge, create media expressions, and communicate with others, in specific life situations contexts[2].

For English language instruction, digital literacy activities can be embedded to foster language learning and digital literacy acquisition that addresses four aspects: "(1) using basic digital skills, (2) creating and communicating information, (3) finding and evaluating information, and (4) solving problems in technology-rich environments" [5]. These activities cannot be separated in integrating digital literacy in language teaching.

The various ways are needed to integrate digital literacy into English language instruction. Students can participate collaboratively for a project or problem-solving activities through teleconference. The interactive skills used in such activity of taking turns, giving opinions, expressing agreement or disagreement, and active listening that provide opportunities for real-world situations to acquire English language [5]. In reading strategies for instance, it is important to use print reading and to consider digital environments that include previewing, predicting, asking questions, monitoring comprehension, and making connections [5].

Literacy in Indonesia is an interesting area of study to be researched. Literacy has been viewed to predict how well a country develops it in education contexts. Most literatures that provide findings on English writing and reading and composition, as well as findings on rhetorical studies, claim that being able to write and read in English is a sign of an individual's literacy existence and growth of [14]. Furthermore, literacy is not only things that are going on inside people's head, cognitive processes of encoding and decoding words and sentences, but also all interpersonal and social processes that relates to a way of developing new ideas and solutions of the problems in reading and writing [13].

\subsection{Teachers' Beliefs and Practice in Using Digital Literacy}

Teachers' beliefs are assumptions regarding to educational issues that is said intended and do as the filter for instructional and curricular decision and actions [6]. Conceptually, belief is defined as individual capability in evaluating self thought, to decide true or not true. The connection of teachers' beliefs and reflective teaching can be explored by questioning; how do teachers' beliefs influence their teaching? [15]. It means that teachers' perception is influenced by the beliefs which affect their action.

In English language teaching, teachers' thought can be affected by their beliefs in doing classroom practices. It is because many aspects of teaching were guided by beliefs as role which relevant to their classroom practices itself. Teachers' beliefs concern to their teaching practices that provide an opportunity to comprehend lesson practices in classroom, so that, teachers can improve many teaching skills [15]. This assumed that beliefs are closely related 
to English language teaching practices, which functioning as background of teachers' action or classroom instructional, which affect the role of engagement of students interaction in classroom and their learning environments [15].

Graves (2000) categorized the framework in articulating beliefs, that are: (1) teachers' view of language, including how the language should be learned; (2) the language social context, including language teaching sociopolitical issues, sociocultural, and sociolinguistic; (3) learning and learner, including the process of discovery and solving of problem in learning by learners; and (3) teaching, including the process of knowledge transmitting to the students, and how the knowledge is negotiated with learning method and students skills.

In line with Graves (2000), many other studies found that the effectiveness and the quality of teaching are affected by teachers' beliefs, especially pedagogical beliefs. It considered as important aspect in guiding the teachers to understand and improve teaching action, including classroom behaviors, judgments, and instructional decisions. Furthermore, teachers' beliefs also construct environment for students that influence their motivation and outcomes in learning [16]. It is assumed that many aspects in learning process including teaching goals and values, teaching roles and contents, and teaching environment are constructed by teachers' beliefs. That becomes the background of making decisions in teaching practice [9].

In similar point to teachers' beliefs, digital literacy also determines the success of language teaching. Digital media and literacy practices can help the students to learn foreign language and give opportunities for them who are wished to navigate professional worlds [17]. In listening course, podcasts are available to add listening opportunities to almost any topic or theme. Assigning students individually to listen to the podcasts, to watch videos on You-tube channel, and other media through internet based. It facilitate teachers to differentiate instruction and to explores many interest and diverse of student needs in order to expand students abilities. In reading course, online texts can be helpful for reading comprehension by using pictures, hyper-links to meaning of word (in English or the students' first language), illustrative videos, and recordings of word pronunciations all provide support written form to meaning. In writing course, the internet offers access to a broad spectrum of potential readers. Students are using their emerging English skills by writing for authentic readers. Writingbased technologies, especially those involving the internet, provide many chances for students to explore their writing skill [5]. In conclusions, teachers' beliefs and digital literacy can be integrated in to the lesson in teaching practices.

\section{Research Method}

This study is designed as case studies, aimed examining lecturer's beliefs and practice in integrating digital literacy into lesson in university level, Padang Indonesia. The participants of this study were four lecturers who teach English reading and writing. The data taken base on lecturers' interviewed following observations in class to explore teacher's practice in using digital literacy. Then, the data were analyzed qualitatively by explaining teachers' beliefs of integrating digital literacy and practice. The characteristics of teachers' beliefs were taken from Grave (2000) that related to teachers' view of language, the social context of language, learning and learners, and teaching [7]. The beliefs of digital literacy were taken from some views [17]; [3], [12] [13]; and [5].

The analysis and discussion of the data were carried out under the research questions identified as research problems of this paper. The open ended questionnaires were also used for exploring teachers' beliefs. Then, teachers' were interviewed following observations in class in exploring teacher's practice in using digital literacy. The participants of this study 
were four lecturers who teach reading and writing. Two lecturers teach reading (lecturer $\mathrm{A}$ and B) and two others teach writing (lecturer C and D). Thus the four lecturers and their 132 students were participated in this study.

\section{Finding and Discussion}

\subsection{Finding}

The data were analyzed into research questions that show lecturers' beliefs on the important of digital literacy in teaching, how digital literacy affects students in learning, and how the lecturers' practice digital literacy in teaching.

At first, the lecturers (A, B, C, and D) were requested to explore about their beliefs and the importance of using digital literacy in classes of Reading and Writing. They are mostly viewed that digital literacy utilization are needed in teaching. They perceive that in welcoming the era of industrial revolution 4.0, the use of digital literacy is very effective in the daily life involving teaching because the students are close with technology. The students can search the literatures they need in learning without lecturers' assistance outside the classroom. The lecturers only facilitate them in such searching the sources recommended.

Furthermore, two lecturers (A and B) perceive that there is cognitive development process in using digital literacy. Digital literacy makes the students accustomed to access reading sources for their knowledge enrichment. While others (C and D) think that it depend on the students whether they want to learn much utilizing digital literacy or not. If the students are diligent to read manually or access digitally reading sources, their cognitive will be developed well. But if they read rarely, it is hard to increase their cognitive.

The second question is about the development interpersonal and social process happened in digital literacy utilization. There are various views of the lecturers in answering this question. Two lecturers (A and D) believe that interpersonal and social process can be happened in using digital literacy. If the students are confused of the instruction, they will communicate it to the lecturer. Then, the lecturer gives the example of e-learning that there is discussion forum in e-learning application. Trough the discussion, the students can be interacted each others. Meanwhile, lecturers (B and C) mention that the interpersonal and social processes are lack in digital literacy utilization. The students work with machine without communicating with others.

In some ways, the all lecturers (A, B, C, and D) believe that in using digital literacy, the students need concern of technical ability in communication with othersin specific life situations contexts. When the students are not able technically using digital literacy, it will make them difficult in using it optimally. More dominant the student in technical skill will be easier they access information and learning resources.

The lecturers believe that digital literacy utilization helps the students in increasing their learning. Although one of them (A) perceives that the students are in transition phase to understand of digital literacy use, but they must use it, because this is digital era. Anything the students want to access can be established in digital devises. While the others (B, C, and D) believe that the students can increase students' learning by using digital literacy.

Moreover, the lecturers (A, B, C, and D) strongly agreed that the students can be master of the skills learned (writing and reading) if they use digital literacy optimally. Writing and reading are closely related to digital literacy used. In writing, for example, the students need to develop their idea by reading much. The source of reading can be established by accessing information trough digital literacy. So, the intensity of sing digital literacy will make them 
fluent in writing. Then, as the receptive skill, reading skill needs much information to be accessed that digital literacy accommodate this need for the students.

The last questions are about lecturers' practice of using digital literacy in teaching and assessment. In practicing, lecturer A do not use digital literacy as the main media, but only as the aid in teaching, as the reason students readiness in using digital literacy. If the lecturer put digital literacy as main media, it will be complicated way for students if it is become the demand of the lecturer. In assessment lecturer A usually uses e-learning for task submission. Then, lecturer B uses digital literacy especially in searching international journal in internet. In assessment, she uses e-learning to collect students' task, but it is rarely done by the lecturer. Lecturer $\mathrm{C}$ recommends the students in searching e-book, journal and online-text in internet. So, the students utilize digital literacy in fulfillment of learning and task. The last, lecturer does digital literacy practice by uploading teaching material in e-learning. She also accommodates online discussion with the students. For assessment, the lecturer usually instructs the students to summarize the article, beside scanning and skimming the text through online text.

\subsection{Discussion}

As the finding shows in this study that the lecturers' perspectives about the importance of digital literacy is the potential consideration in practicing it at classroom. Unfortunately, it was not optimal yet to practice, because integrating digital literacy into lesson is challenging for both the lecturers and students. Because of technology changes rapidly, language teachers are in position of challenging the intersection of possibilities of using digital literacy, teaching with digital texts and using social media, or teaching not with digital texts and social media [1]. This condition influences their practice that a little bit different with what their beliefs. That is because the digital environments they use reduce opportunities of teachers interaction with students.

The concept of digital literacy is understood to be closely related to learning processes as social practices, as the examples of how digital literacies can be introduced and performed in courses and educational programs within teacher education are given [18]. The finding of this study are closely related to finding of Olsson \& Edman-Stalbrant's research that the lecturer have the effort to integrate digital literacy, although it is not as what they believe about digital literacy itself [18].

\section{Conclusion}

Based on the findings, it is possible having conclusion that the lecturers who teach writing and reading in university have a strong belief that it is important to integrate digital literacy into the lesson. They perceive that using digital literacy bring the students to cognitive development. Then, some of them are sure that in digital literacy utilization appears interpersonal and social interaction process, while some others think that lack of social interaction in digital literacy. So, the lecturers believe that technical skill is essential in utilizing digital literacy. In addition, the lecturers also think that the digital literacy integration into lesson affect the students' acceleration in learning, because it help the student to enrich their knowledge through technology. In practice, the lecturers use digital literacy limitedly on e-learning that must be used in the university as the requirement. In reading, not all of them optimally use others program such as using images, hyperlinks to word meanings, illustrative videos, and recordings of word pronunciations in supporting written form to meaning for 
reading. In writing, only one the lecturer offers writing-based technologies that those provide opportunities for students to be writers. While the other one only uses e-learning as the activities of task demand. In conclusion, this research suggests that the lecturers should balance the reflection of their beliefs in instructional practices, in order to have all inclusive understanding of teachers' beliefs and practices related to digital literacy.

\section{References}

[1] C. K. Kinzer, "Considering literacy and policy in the context of digital environments," Lang. Arts, vol. 88, no. 1, 2010.

[2] J. P. Guikema and L. Williams, "Digital Literacies from Multiple Perspectives," in Digital literacies in foreign language education, vol. 12, Texas: CALICO Monograph Series, 2014, pp. 1-8.

[3] J. Sharkey and D. S. Brandt, "Integrating Technology Literacy and Information Literacy," in Digital Literacy: Tools and Methodologies for Information Society, Harshey: IGI Publishing, 2008, pp. 85-98.

[4] A. Gruszynska, G. Merchant, and R. Pountney, “'Digital Future in Teacher Education': Exploring Open Approaches towards Digital Literacy,” Electron. J. e-learning, vol. 11, no. 3, pp. 193-206, 2013.

[5] K. Harris, "Integrating digital literacy into English language instruction: Issue brief," pp. 1-9, 2015.

[6] T. Levin and R. Wadmany, "Teachers' Beliefs and Practices in Technology-based Classrooms : A Developmental View," J. Res. Technol. Educ., vol. 39, no. 2, pp. 157$182,2008$.

[7] K. Graves, Designing Language Courses: A Guide for Teachers. Boston: Heinle\& Heinle Publishers, 2000.

[8] L. Xu, "The Role of Teachers ' Beliefs in the Language Teaching-learning Process," Theory Pract. Lang. Stud., vol. 2, no. 7, pp. 1397-1402, 2012.

[9] M. E. G. Pelaez, "English Teachers' Beliefs about Communicative Competence and their relationship with their Classroom Practices," Profile Issues Teach. Prof. Dev., vol. 10, no. 1, pp. 75-90, 2008.

[10] H. Lotherington and J. Jenson, "Teaching Multimodal and Digital Literacy in L2 Settings : New Literacies, New Basics, New Pedagogies,” pp. 226-246, 2011.

[11] R. A. Akbar, M. Akhtar, A. Hussain, and M. Abiodullah, "Beliefs and Practices of Teacher Educators Teaching B. Ed (Hons) and ADE in Universities and Affiliated Colleges in Punjab," Bull. Educ. Res., vol. 35, no. 2, pp. 91-106, 2013.

[12] D. Bawden, "Information and digital literacies: A review of concepts," J. Doc., vol. 57, no. 2, pp. 218-259, 2001.

[13] R. H. Jones and C. A. Hafner, Understanding digital literacies: A practical introduction. New York: Routledge, 2012.

[14] S. S. Sukandi and Y. Yulmiati, "EFL Students' Learning Styles on English Academic Writing at University Level in Indonesia," Adv. Soc. Sci. Educ. Humanit. Res., vol. 276, no. Icoelt 2018, pp. 172-181, 2019.

[15] B. Mamo and A. Yigzaw, "EFL teachers' conceptions and attitudes of peer-assisted learning in English classes," Ethiop. J. Educ. Sci., vol. 11, no. 2, pp. 17-32, 2016.

[16] O. Zhukova, "Novice Teachers' Beliefs About Problem-Based Learning Approach, and Teaching Practices," in CBU International Conference Proceedings, 2017, vol. 5, pp. 901-909. 
[17] S. L. Thorne and R. W. Black, "Computer-Mediated Contexts and Communities," no. 2007, pp. 133-160, 2008.

[18] L. Olsson and E. Edman-Stålbrant, "Digital literacy as a challenge for Teacher Education,” Learn. to Live Knowl. Soc., vol. 281, pp. 11-18, 2008.

\section{Acknowledgments}

The researchers intend to say special thanks for STKIP PGRI Sumatera Barat in supporting this research conducted. In addition, for our colleagues to whom the data have been collected, we want to give our appreciation and thanks for your cooperative response in giving the information related to your beliefs and practice in using digital literacy in teaching. 